\title{
Perceptions of Medieval Settlement
}

\author{
Mark Gardiner and Susan Kilby
}

The approach to the perception of landscape and settlement adopted by medieval archaeologists has been rather different to those of their colleagues working on the prehistoric period. To a large extent such differences can be attributed to the quality of the evidence. Many of the studied medieval buildings still survive, albeit often as ruins. The landscape with its pattern of roads, fields and farms can be largely reconstructed in broad terms, and sometimes in detail. This sort of material both informs our understanding of past perceptions of landscape, but also serves to constrain the way we might interpret it. The type of imaginative reconstruction advocated, for example by Tilley (2010, 30-31), in which the archaeologist places themselves within the landscape and responds to the experience has been practised only rarely for the historic period. It is not that medievalists lack the imagination of prehistorians, but rather they do not feel the need to embark upon discussions of their particular experience of place when it is possible instead to reflect upon how those in the Middle Ages may have perceived their surroundings.

A simple contrast between the medievalists' and the prehistorians' approaches to the perception of landscape is, however, misleading. Embodiment or the experience of place using the senses of the body occupying and moving through a place has been practised by both groups, but with different emphases. To stand in a medieval building and look out at the vista beyond is to adopt a phenomenological approach. It does not become less so if the appreciation of the view is informed by the knowledge that in the late Middle Ages the area in the foreground would have been occupied by gardens and that in the distance by woodland. That information adds a depth to the experience. The medieval archaeologist can further enrich their understanding of the meaning of the landscape and the experience which may have been evoked if there is also some knowledge of the stories associated with places - the lieux de mémoirelocations which evoke social memory. Such a rich reading of the landscape has been given, for example, for Peak Castle in Derbyshire. The castle stood on the hill above a cave listed amongst the four wonders of England, according to the twelfth-century historian, Henry of Huntingdon. It was said that the wind from the cave blew with such force that it could strip clothing off people and blow it up into the sky. The castle was constructed on top of this rather magical place and its design contrived to make the greatest impact. The position of the great tower, and its 
Chapter accepted in Kilby, SE;Gardiner, M, Perceptions of Medieval Settlement, 'Handbook of Later Medieval Archaeology', Oxford University Press (in press)

'angle, design and fenestration were carefully manipulated'. Its windows were orientated to Mam Tor on one side and Hope church on another (Barnwell 2007, 22-33). The legend and the building itself fed off one another to produce a stronger sense of the power of place.

This preamble situates the particular approaches of late medievalists to the perception of settlement within the wider archaeological interest in phenomenology. The richness of the medieval record has allowed the embodied response to place to be augmented by an understanding of context, not so that one might replace the other, but might add to the experience. The value of a combined approach can be best appreciated by looking at a further castle site. Cooling Castle in the north of Kent has recently been discussed by an historian and English scholar, Cristina Maria Cervone (2008), and an archaeologist, Matthew Johnson (2002, xiii-xix) - the former taking a literary, if wide-ranging approach to one aspect of the site, the unusual plaque attached to the outside of the gatehouse, and the latter adopting a rhetorical view of their appreciation of the building. For Cervone, who is concerned with texts, the key element of the castle is the plaque which reads:

Knouwyth that beth and schul be

That $\mathrm{i}$ am mad in help of the cuntre

In knowyng of whyche thyng

Thys is chartre and wytnessyng

The plaque takes the form of a charter with appendant seals and the initial words echo the common opening of such a document (Sciantpresentes et futuri...), as a medieval reader would have immediately appreciated, and alludes to a licence to crenellate. The text, however, unlike such a licence, is in the vernacular and is cast in the form of a poem which makes it clear that it is by no means a simple quotation of a legal text. The most striking thing about the wording is that it gives the building a persona ('I am made...'). The building seems to speak to the viewer.

Another, more succinct text appears on the nearly contemporary Pipewell Gate at the entrance to Winchelsea (East Sussex), and reads:

\section{Helde}

This has been interpreted, as no doubt was expected by those who placed in there, as a reference to John Helde, mayor of Winchelsea in 1399 and 1404 (Salzman 1937, 63). But equally it was also intended to be read as 'I held', a reference to the survival, either of the gatehouse, or perhaps the town more generally, when attacked by the French in 1380 (Martin and Martin 2004, 
Chapter accepted in Kilby, SE;Gardiner, M, Perceptions of Medieval Settlement, 'Handbook of Later Medieval Archaeology', Oxford University Press (in press)

62). The persona of this building was the endurance of the town. Both Cooling Castle and Pipewell Gate were given voices which make explicit that these were not to be seen as merely inanimate objects, but were intended to serve as personifications of their builders, in first case of John de Cobham and in the second of the town of Winchelsea. Their inscriptions speak of an increasingly literate population which might be addressed with texts intended to intrigue through their ambiguities. More generally, these buildings provide evidence for the argument that late medieval settlements and their settings were intended to convey complex messages, rarely 'vocalized' as in these examples, but always present.

\section{Lordly farmsteads}

Medieval houses were planned both as places to be seen by the approaching or passing visitor (the reflective view), and as places from which to look out from (the projective view). The careful contrivance of the appearance of buildings to impress the visitor is evident from at least the ninth century onwards, when the angles of the walls and the roof of major halls were subtly altered to make them appear both longer and taller than they were (Gardiner 2013, 63-69). By the twelfth century the emphasis in contriving an appropriate appearance for lordly buildings had moved to placing the hall towards the front of the site, so that it or the gatehouse in front of it was clearly visible to those approaching and passers-by (Gardiner forthcoming). At Wharram Percy (East Yorkshire), for example, the mid-twelfth-century hall was located so that it appeared on the skyline when viewed from the green below (Everson and Stocker 2010, 265), while at Castle Acre the enclosure was provided with a gatehouse and subsequently the 'country house' set within it was converted into a great tower which dominated the site of the town below (Coad and Streeten 1982, 191-193). However, apart from castles, there have been few studies of the means by which later lordly dwellings were constructed to impress the visitor. There is no doubt that the arrangement of a suitable approach to the entrance door was a major consideration in the plan of a gentry hall, just as it was to a castle. Campbell $(2014,178-179)$ has argued that even seemingly irregular designs, such as Hextalls (Surrey) were in fact carefully and metrically laid out. Yet, contriving a design which served to provide an impressive façade and worked as a satisfactory internal space was a difficult task. The interior of the late medieval hall had a plan which did not allow much scope for variation. The entrance was conventionally located at one end of the hall, while the largest windows had to be set at the other in order to illuminate the lord's seat at the table. Campbell has shown that one means of resolving the desire to produce a balanced façade and the need for these features in the interior was to treat them as equal elements in the design. The large window illuminating the lord's seat was commonly projected 
Chapter accepted in Kilby, SE;Gardiner, M, Perceptions of Medieval Settlement, 'Handbook of Later Medieval Archaeology', Oxford University Press (in press)

forward in the fifteenth-century house to form an oriel window and designed so that it echoed the two-storied porch of the main entrance. Similarly, at one end of the house beyond the hall the services containing the kitchen and stores might be constructed to reflect the chamber set at the opposite end (Campbell 2014, 179-181). In that way the front of a gentry house could be designed to present a show-façade to the visitor.

Castles offered an image of martial strength which also conveyed a strong sense of social status. Even for lesser lords who could not afford the expense of a grand fortified building, the castle form carried such prestige that it might be imitated in more modest, if scarcely defensible structures. The Old Manor House in Walmer (Kent) constructed perhaps in the early twelfth century appears to be a copy in miniature of the nearby great tower at Rochester Castle (Fernie $2000,84)$. Turrets were constructed at the four corners of the Walmer house, though three of them were so small that they served little apparent purpose while the fourth only housed a stairwell. The building was entered, as at Rochester, from a projecting staircase, first built in timber and later replaced in stone (Philp 2011). Weeting 'Castle' (Norfolk) built some fifty years later less obviously evoked martial forms, since it balanced 'lordly and domestic functions within a single architectural structure' (Heslop 2000, 54). The aisled hall is wholly domestic, but the attached chamber block seems to mimic the form of a great tower. It was entered at first-floor level by an external staircase which unusually could not be reached directly from the interior of the hall. On either side of the interior of the entrance were deep niches which have been compared with those in the gateway of Castle Acre castle. The chamber block was three stories high, creating a building of imposing grandeur, but this was in fact an entirely domestic building, as the projecting latrine block concealed at the rear indicates (Heslop 2000).

Both the houses at Walmer and Weeting were set within large moats, or at least ditched enclosures since it was unclear whether they were water-filled. Such ditches provided a framing device for the buildings set within, and visitors approached the entrance over a bridge which provided further opportunities for managing the display of the façade. Fenwick $(2012,290)$ has noted that in the Humber lowlands moats were often located besides waterways and it is possible that these were intended to be viewed by travellers along the rivers. The extraordinary density of moated sites in some areas of the country, particularly parts of Worcester, Essex and Suffolk, argue that they were not only dug around the houses of the wealthy gentry (Aberg 1978, fig. 1). They also served the aspirant peasants as a mark of status. Roberts characterized these people in the Forest of Arden (Warwickshire) as: 
Chapter accepted in Kilby, SE;Gardiner, M, Perceptions of Medieval Settlement, 'Handbook of Later Medieval Archaeology', Oxford University Press (in press)

a group of wealthy freeholders who accumulated land to create sub-manors, and who demonstrated this wealth in the construction of large moated farmsteads (Roberts 1968, 112).

Although the value of security offered by moated sites was no doubt also in the minds of the builders, this hardly seems the sole or even main consideration in their construction (cf. Platt 2010). The moat was evocative of the idea of a fortified residence, even if it was not defensive.

Houses were not merely buildings to be seen, but also places to look out from, as has already been noted. Window seats, which were common in stone buildings from the early thirteenth century, suggest how much time must have been given to watching and presumably enjoying the view (Wood 1965, 346-47). In one of the earliest surviving examples, the windows with their seats on the first-floor of Moyse's Hall (c. 1180), Bury St Edmunds (Suffolk) look out directly on to activity in the market place. A century earlier a timber balcony had been constructed at Scolland's Hall in Richmond Castle (North Yorkshire) to look down the Swale valley and perhaps also into a garden immediately beneath. That balcony was accessible only from the main chamber, but a second longer one ran the length of the hall and seems to have been reached directly from the bailey, and therefore may have been accessible to a greater range of occupants with the castle. It provided a dramatic view across the Swale valley, the sides of which fell sharply away beneath (Fig. 1; Peers 1953, 19-20). The elevated position occupied by castles and the views from tall towers were appreciated as much in the late Middle Ages as they are now. McNeill $(2006,123)$ has examined five towers of the period around 1300 which have evidence for stairs leading from private quarters to the roof and concluded that they were intended for the enjoyment of the view by the lord. Girouard reached a similar conclusion about the broad walk around the battlements on the fifteenth-century tower at Tattershall (Lincolnshire). This, he suggested, was intended 'more for after-dinner strollers than for soldiers' (Girouard 1978, 78). Perhaps the most remarkable of viewing places is Longthorpe Tower (Cambridgeshire) in which the great chamber was decorated internally, not only with biblical and allegorical figures, but also with birds 'mostly of a type likely to be found in the nearby fenland... bittern curlew and various kinds of goose or swan' (Rouse 1964, 10). McNeill (2006, 126) comments that while it may not be credible to suggest that Sir Robert Thorpe, the lord of Longthorpe, was a keen bird-watcher, he may well have been an acute observer of wildlife in the countryside around.

When we consider these buildings, the argument that the capacity to perceive and enjoy landscape was a development of the fifteenth century, as claimed by Cosgrove (1985) and others, 
Chapter accepted in Kilby, SE;Gardiner, M, Perceptions of Medieval Settlement, 'Handbook of Later Medieval Archaeology', Oxford University Press (in press)

seems unpersuasive. The medieval eye may have perceived a different landscape from that which we see, for our view has been influenced by the concepts of the romantic movement. However that is quite different from arguing that people in the late Middle Ages did not enjoy the elevated views which were offered from the upper rooms and roofs.

\section{Peasants' experience of space}

Establishing the way in which peasants thought about and viewed their surroundings is considerably more problematic than considering the elite perspectives on the world. Peasants rarely wrote about their understanding of their world, but their actions are often written about in the vast corpus of manorial documentation that survives for this period in England. Since peasants were not the authors of these myriad documents, it is argued, there is little to be gained in using them to elucidate peasant mentalities. In recent years, however, historians and archaeologists have begun to reconsider approaches to the study of the late medieval settlement, to the extent that the scholarly pursuit of peasant mentalities, in particular concerning their conception of their environment, is now being taken up more widely (Müller 2001; Altenberg 2003; Whyte 2003; Stone 2005; Olson 2009; Kilby 2010; Smith 2010; Jones 2011; Gardiner 2012; Mileson, 2012).

Manorial sources were produced on behalf of lords, but it is possible to detect and isolate the peasant voices therein (Kilby 2013, 72-77). Scholars have suggested that in particular, names - both personal names and those bestowed upon the landscape - can offer a gateway into the mental world of the lower orders (Kilby 2010, 72; Gardiner 2012, 17; Jones 2012, 260; Mileson, 2012, 92). It is generally accepted that field-names were conceived by peasant farmers, with the earliest evidence for these appearing in the late Anglo-Saxon period. Archaeologists and linguists have long identified the mutual benefits to be gained in assessing local field-names, and in current scholarship, field-names and other minor landscape names are being used as a means of accessing peasant mentalities. Assessing the changing nature of the perception of prehistoric burial mounds across a long chronological period, Semple and Whyte used place-names respectively as part of a wider range of evidence (Semple 1998, 111-112; Whyte 2003, 6). Following the work of anthropologists and ethnographers, archaeologists and historians are beginning to view the landscape - and the names associated with it - as a repository for history and folklore, and therefore closely associated with collective memory. Although at present this emerging field of enquiry is dominated by scholars of the Early Modern period - for which a 
Chapter accepted in Kilby, SE;Gardiner, M, Perceptions of Medieval Settlement, 'Handbook of Later Medieval Archaeology', Oxford University Press (in press)

greater quantity of documentation survives - medievalists are beginning to show that similar attitudes prevailed in the late medieval period (Gardiner 2012, 17; Kilby 2013, 138-165).

For many peasants throughout England - but most especially serfs living in highly manorialized areas - their obligations to labour on the lord's land meant that they enjoyed largely open access to the fields beyond the settlement, through a system of roads, paths and headlands; although certain areas of the lord's home farm (the demesne) and private resources such as parks, warrens and fisheries might be subject to more rigorous controls concerning access (Creighton 2009, 111-112, 160). Walled, gated and moated elite residences have been interpreted in a number of ways: as a means of conveying information about status and power, for defensive purposes, and to ensure privacy (Liddiard 2005; Creighton 2009, 53-57; Platt 2010, 125). By contrast, little has been written about peasant notions of privacy, although Astill noted that numerous surveyed English peasant tofts showed a tendency for ditched, fenced or walled boundaries, suggesting that it might be an important factor. He suggested that set behind hedges, it would have been difficult to see into most tofts (Astill 1994, 53; Dyer 1994, 139). This is supported by documentary evidence in many instances: the homestead of a prominent Castor (Northamptonshire) freeman was described in 1319 as being walled, hedged and ditched; and a plot of villein land 'enclosed with hedges and ditches' in Winslow (Buckinghamshire) was granted out in 1335 for the purposes of building a house (NRO F(M) Charter 254; Noy 2011, 57). However, a more complex recent analysis by Mileson and Brookes (forthcoming) has suggested that houses set close together in the centre of a village more often had immediate access to the road, while isolated houses and those set in smaller clusters may have been less visible from the road. Privacy was more rigorously protected in places where it already existed, but in the centre of a village where houses were already set close together, there was less effort to establish it.

Privacy is both about the freedom to be alone and remote from public gaze, but also freedom from intrusion. John Horold of Lakenheath (Suffolk), who was almost certainly unfree, seems to have been particularly determined to delineate the bounds of his tenement, suggesting his interest was in recording the limits of his private property, despite the fact that, notionally, at least, servile peasants' property legally belonged to the lord. In 1325 he paid a fine for an inquisition to assess the perimeter, and to place bounds between himself and his neighbour. After a further incident a few years later involving the theft of several trees from his yard by another neighbour, he once again requested that the court set the bounds (CUL/EDC/7/16/II/1/8/15; CUL/EDC/7/16/II/1/9/7; CUL/EDC/7/16/II/1/6/38). 
Chapter accepted in Kilby, SE;Gardiner, M, Perceptions of Medieval Settlement, 'Handbook of Later Medieval Archaeology', Oxford University Press (in press)

This concern to establish boundaries between quarrelsome neighbours is echoed in court cases at Sevenhampton (Wiltshire), where it was granted that bounds should be placed between the properties of two men, following a trespass committed by one of them; and in a similar case at Walsham (Suffolk) (Pugh 1970, 44; Kilby 2015, 83). Even in cases where boundaries are not expressly mentioned, it is clear that in a number of neighbourly spats at Lakenheath, longrunning disputes lasting several years often resulted in peasants entering neighbouring properties and causing deliberate damage to gates, fences and walls (CUL/EDC/7/16/II/1/6/24 and 41; CUL/EDC/7/16/II/1/9/13). In these cases, there was no record of any theft, but the fact that peasants brought court action against this kind of unneighbourly behaviour emphasises that breaking a neighbour's boundary was considered to be a breach of their privacy. This is supported by evidence contained in land transfers: even where tofts and messuages were being transferred or shared within families, there was often a clause recognizing that the new tenant ought to have 'free ingress and egress' to and from the toft, indicating that this did not always happen, and that attempts were made to regulate, and in some instances, restrict access (Kilby 2013, 256; Smith 1982, 35). It was inevitable, of course, that peasants might enter each others' tenement at some times, but they sought to create a distinction between the space into which any visitor might come on business and the more private space of the house. This is apparent at Great Linford (Buckinghamshire) where the brewhouses from which ale might be sold were placed to the front by the street and the houses set back behind, and a similar arrangement can be seen in the late fourteenth- or early fifteenth-century smithy and house at Goltho (Lincolnshire) (Fig. 2; Mynard and Zeepvat 1991, 51-91; Beresford 1975, fig. 5).

Perhaps we should be unsurprised that boundaries were of great interest. Local peasants were seen as the custodians of the memory and knowledge of the parish boundaries, and prominent and elderly residents were expected to be able to convey information concerning boundaries should it be required, sometimes in order to settle disputes. In some instances where villages shared resources across a boundary, older men were usually selected to set or re-establish frontiers, since their memory extended beyond that of younger men. This is demonstrated in the division of a Lincolnshire fen in the twelfth century, where one assessor was described as 'an old and wore out man' (Hallam 1965, 167). Many disputes are recorded concerning shared resources. Once again, it can be seen that prominent, older men were called upon to re-apportion a Suffolk fen between Wangford and Lakenheath (CUL/EDR/G3/28/Liber M). There is limited evidence for Rogation processions in this period, but it was the time of year when knowledge about the bounds and the local environment was transmitted and remembered (Blair 2005, 487-88). At Elmley Castle (Worcestershire) in 1449, the court ordered all tenants over the age of twelve to 
Chapter accepted in Kilby, SE;Gardiner, M, Perceptions of Medieval Settlement, 'Handbook of Later Medieval Archaeology', Oxford University Press (in press)

participate in the Rogation procession 'to survey and make anew all the metes and bounds of th[e] lordship' (Field 2004, 122). This rare evidence for a late medieval Rogation procession suggests that in this case, too few tenants were taking part, and that generally these ceremonies passed without any need for the court's involvement. The need for a clear agreement of the line of parish boundaries is evident in those cases where such knowledge was lacking. At Elton (Huntingdonshire), the jurors presented a number of encroachments made by the tenants of adjacent villages on to their meadow - a problem that remained unresolved after more than twenty years, although clearly remaining a significant issue (Ratcliff and Gregory 1946, 96). Similarly, at Great Cressingham (Norfolk), the court attempted to penalize men from the neighbouring parish of Hilborough for damaging their common; and the parishioners of Mildenhall (Suffolk) built an embankment in Lakenheath one league long and ten feet wide, thus diverting a watercourse and causing grievous damage to Lakenheath peasant land (Chandler, 1885, 23; CUL/EDC/7/16/II/1/9/20).

The separation of private land and public space may have been clearly understood, but the ways in which communal areas might be used were sometimes a cause of contention. Medieval court rolls abound with countless cases involving peasant self-interest. Many thought nothing of blocking roads and paths. At the Wakefield (West Yorkshire) court in November 1332, thirteen men were fined for obstructing rights of way with dungheaps, logs and heaps of $\tan ($ Walker, 1983, 127). In some instances, peasants dug up the common highway. In Stanley (West Yorkshire), Adam Isbell sank pits in the road to dig for coal; similarly at Elton, Hugh Prest dug a pit in the road outside his house (Walker 1983, 110; Ratcliff and Gregory 1946, 119). At Sevenhampton, Walter Tailor built a wall that encroached on the king's highway, and at Brandon (Suffolk), John Crowe made a trench in the road that he was ordered to repair (Pugh 1970, 79; Bailey 2002, 228). In some instances, it is clear that the court presentments outline the licensingand, in effect therefore, the sanctioning - of peasant actions on common or demesne land. At Ossett (West Yorkshire), Hugh Sonman paid a fine of a shilling to dig an iron mine in one of his selions, and here, as elsewhere, clearly the lord was keen to benefit financially from a potentially revenue-generating enterprise (Walker 1983, 121).

Areas of land which served for communal activities were to be found in many villages. They might be used for sports and recreation, for commerce and for other gatherings. In 1481 in Bethersden (Kent) a group of local men, led by their vicar, refused to accept that a piece of land alleged by them to be common ground and used as their football pitch, was to be appropriated and ploughed up by the lord's new tenant. On the day that the pitch was to be ploughed, the 
Chapter accepted in Kilby, SE;Gardiner, M, Perceptions of Medieval Settlement, 'Handbook of Later Medieval Archaeology', Oxford University Press (in press)

unruly gang prevented access to the farmer, and 'riotously' played football for almost the whole day, destroying the plough, and scattering it across the field (TNA/KB/9/365). ${ }^{1}$ Similar places for playing camp-ball, a combination of football and handball, have been identified across East Anglia (Dymond 1990). Such areas were often situated close to the churchyard and may also have been used for archery practice and maypole dancing (Hutton 1994, 30-31). Some churchyards served both for sports, drama and, in Scotland at least, for archery practice. The struggle between the competing conceptions of the parish churchyard as a sacred space and a place for communal uses of all sorts continued throughout the later Middle Ages and beyond (Dymond 1999, 467-483).

Peasant behaviour on demesne land, or in woods, warrens, parks and fisheries is more difficult to interpret. Undoubtedly, some peasant access was licensed, but it is possible to detect other acts that give the impression that many local peasants may have been aware that certain parts of the manorial environment were out of bounds, but that this did not deter them from gaining access regardless — the most obvious acts relating to poaching. Undoubtedly, the group of Lakenheath boys caught setting snares and traps in the doorway of the lord's dovecote in 1332 knew that they were trespassing (CUL/EDC/7/16/II/1/9/9). And yet, where peasants' own land — whether notionally private, or communal — was under threat, remedial action was often taken.

Unravelling peasant mentalities regarding local landscape requires us to assess different aspects of the landscape separately. Peasants had different attitudes to spaces within the settlement, regarding some as strictly private and rarely to be entered. These included the lord's farmstead and some of the tofts of the more wealthy peasants. The tofts of other peasants, though viewed as private space, and often ditched, hedged and gated, might be entered in certain circumstances. Despite the strong assertions of ownership displayed when considering interests that were most clearly personal or communal, it was not uncommon for late medieval peasants to overlook temporarily the fact that they might need permission in order to access certain other areas, to appropriate additional land, or to use resources that they had rented for purposes other than those already agreed. Where these more selfish acts impacted the whole community and were seen as a nuisance to all, such as digging holes in the road, or building walls upon it, they were usually swiftly brought to the court's attention.

\section{Perceptions of the spiritual in the countryside}


Chapter accepted in Kilby, SE;Gardiner, M, Perceptions of Medieval Settlement, 'Handbook of Later Medieval Archaeology', Oxford University Press (in press)

By the time of the Reformation the countryside of Britain was permeated with places of sanctity (Walsham 2011, 40-48). These extended far beyond the established sacred spaces - churches, chapels and monasteries - to places associated with saints, sites which were still or had once been occupied by hermits, and also holy wells. The progressive accretion of contemporary holy sites and remembered places provided late medieval Britain with numerous locations which were sacralized. Most of these types of holy site are discussed elsewhere in this volume. It is necessary here only to comment on the range of places associated with saints and to consider the role of hermits in establishing a sacred landscape.

Saints' cults attracted pilgrims and, in what has been described as a symbiotic relationship, local details were added to saints' lives exploiting the topographic associations and providing further cultic places for the pilgrims to visit (James 1993, 105). In the countryside around the town of St David's (Pembrokeshire) were a series of chapels which provided additional sites for the pilgrims journeying to the cathedral. Amongst these was the chapel and holy well at Porth Strinian. The cove below the chapel was named after Justinian who had come from Brittany to join David on Romsey Island. He was killed by his servants and a spring appeared on the spot which by the fourteenth century was noted for miraculous cures. The body of the murdered Justinian was initially buried in the chapel close to the spring, but his remains were later translated to St David's cathedral (James 1993, 106-107). In additional to the various chapels around the cathedral town, Rhygyfarch's eleventh-century Life of St David includes reference to a large number of other places localizing the saint's cult - Portus Magnus (Porth Mawr), Vetus Rubus (unlocated near St David's), Vallis Rosina (the valley of St David's) flumen quod dicitur Alun (River Alun), Martirium Dunaut (unlocated spring near St David's), and Porthlysgi was evidently connected with Lisci, a local aristocrat who killed an opponent of St David (Sharpe 2007 on the text, and place-names identified in Sharpe and Davies 2007). The whole countryside around St David's was filled with holy places or sites with a close connection to life of the saint.

It was not only the area around pilgrimage centres which produced cultic sites. Many, probably most, Anglo-Saxon minsters were the burial place of saints and there were many significant places in the local landscape connected with their lives (Blair 1997; Blair 2002). Memory of some of these persisted into the late medieval period, but in addition there developed many further sacralized sites across Britain, some at natural locations, such as springs, and others at shrines or crosses which had shown miracle-working properties. The ecclesiastical authorities did not so much repress these cultic places as seek to manage the enthusiasm which they engendered, putting down only those which threatened their authority (Watkins 2007, 96-97, 
Chapter accepted in Kilby, SE;Gardiner, M, Perceptions of Medieval Settlement, 'Handbook of Later Medieval Archaeology', Oxford University Press (in press)

108; Walsham 2011, 67). But if much of the countryside of late medieval England had places with holy associations, there were other areas which were deemed less firmly within the orbit of God's grace. These were places at the margins, particularly woodlands and marshes, and more generally environments far from human habitation (Gardiner 2008, 299-300; Rippon 2009, 4749). Unlike the well-settled lands where the sanctity was concentrated in numerous, but particular places, the locations on the margins where malevolent forces might be present were diffuse and extensive. These areas were deemed to be the haunt of ghosts and demons in the Middle Ages such as the woodland between Peterborough and Stamford, where in the twelfth century, a wild, spectral hunt with black horses, hounds and even goats was regularly witnessed - and locations at which suicides and executed criminals might be buried (Mellows and Mellows, 54-55; Reynolds 2009, 247-48). Surviving minor names, such as the field-names thirspitt (demon's or giant's pit) in Ailsworth (Northamptonshire) and drakecrundell (dragon's pit) in South Creake (Norfolk) also identify places associated with the supernatural (BL/Cotton MS Nero C. vii/14; Hesse 1998, 80-84). And in some instances, major place-names indicate the setting for both the demonic and the miraculous: at Drakelow in Derbyshire, two peasants apparently struck down by St Modwenna arose as revenants to terrorize the neighbourhood. Drakelow means 'dragon burial mound/hill', and so here, the landscape provided the obvious setting for the local legend, and the conjunction of place-name and folklore is unlikely to have been accidental (Harte 2003, 180; Watkins 2007, 183).

One means of neutralizing such godless spaces was to settle them with holy men and establish centres of Christianity which might sanctify such regions and make them safe for lay people. The model for such activity was the early eighth-century hermit and saint, Guthlac who established a monastery on the demon-haunted site at Crowland. By the eleventh and twelfth centuries, hermits were choosing to live not so much in the utter wilderness, but just beyond the margins of settlement, not least because hermitages in very remote locations were unlikely to attract alms. We can suggest that one of the (unacknowledged) roles of the hermit was to establish sanctity at the margins of settlement, effectively beginning the process of the sacralization of the landscape. A hermit on his own was a minor force in the preparation of land in this way, but a well-regarded eremite could attract followers, and in time these might take on the more formal character of a religious community, sometimes developing into a monastery (Herbert 1985; Licence 2003; Licence 2011, 97-105). The site on the edge of an area of peat moss and beside the sea at Cockersand in Lancashire near the mouth of the River Lune was occupied first in the early 1180 s by a hermit, Hugh Garth. He attracted sufficient alms and 
Chapter accepted in Kilby, SE;Gardiner, M, Perceptions of Medieval Settlement, 'Handbook of Later Medieval Archaeology', Oxford University Press (in press)

followers that the site was transformed in due course into a hospital and by 1190 into a priory, later raised to the status of an abbey (Farrer, 1898, ix-x).

In archaeological terms we could see that the role of such pioneers was to establish the outlines of a particular form of encultured landscape in which it was deemed safe to settle. The landscape was sacralized, made safe for occupation because in the foundation of a hermitage it had acquired its first religious outposts. However, that pioneering work of hermits was largely done by the thirteenth century, as settlement had been pushed into even remote areas of Britain and by the fourteenth century hermits had largely left their wilderness sites to occupy positions on roads and by bridges where they took on the task of their repair, such as the hermit who lived near bridges adjacent to the river Cam in Cambridge in the late fourteenth-century (Cam 1959, 114; Jones 1998, 53-55). The historian Wace was surely right when he wrote that the mysteries of the wood of Barenton in Brittany had disappeared with the spread of settlement, although in many places, field-names recorded in the late medieval period suggest the continued memory of both sacred and demonic sites for a time (Burgess and van Houts 2004, 162).

\section{Conclusions}

Our understanding of how people in late medieval Britain perceived their landscape is still at an early stage. While much attention has been devoted to seigneurial perceptions of space, largely confined to the rather narrow field of castles, much less work has been devoted to the way in which peasants conceptualized the landscape which they occupied. The study of the perception of the spiritual has been almost entirely limited to established religious sites, which fails to reflect the thorough penetration of the sacred into the mundane world. If these aspects of late medieval archaeology have remained underdeveloped, it is because approaching the way the world was experienced by people in the past is bound to prove challenging. In recent years archaeology has increasingly turned to think in greater detail about perception as it has become clearer that the thought-about world and the experienced world, two interlinked aspects of perception, played a significant role in behaviour. There remains much scope for future work in understanding the way in which people viewed their surroundings. 
Chapter accepted in Kilby, SE;Gardiner, M, Perceptions of Medieval Settlement, 'Handbook of Later Medieval Archaeology', Oxford University Press (in press)

\section{Bibliography}

Abbrevations

BL

The British Library

CUL

Cambridge University Library

NRO

Northamptonshire Record Office

TNA

The National Archives, Kew

\section{Published works}

Aberg, F A, 1978 'Introduction', in F A Aberg (ed), Medieval Moated Sites, Council for British Archaeology, London, 1-4

Altenberg, K, 2003 Experiencing Landscapes: A Study of Space and Identity in Three Marginal Areas of Medieval Britain and Scandinavia, Almqvist and Wiksell, Stockholm

Astill, G, 1994 'Rural settlement: the toft and croft', in G Astill and A Grant (eds), The Countryside of Medieval England, Blackwell, Oxford, 36-61

Bailey, M, 2002 The English Manor c.1200-c.1500, Manchester University Press, Manchester

Barnwell, P, 2007 'The power of Peak Castle: cultural contexts and changing perceptions', Journal of the British Archaeological Association 160, 20-38

Beresford, G, 1975 The Medieval Clay-land Village: Excavations at Goltho and Barton Blount, Society for Medieval Archaeology, London

Blair, J, 1997 'Saint Cuthman, Steyning and Bosham', Sussex Archaeological Collections 135, 173-192

Blair, J, 2002 'A saint for every minster? Local cults in Anglo-Saxon England', in A Thacker and R Sharpe (eds), Local Saints and Local Churches in the Early Medieval West, Oxford University Press, Oxford, 455-494

Blair, J, 2005 The Church in Anglo-Saxon Society, Oxford University Press, Oxford

Burgess, G S (trans) and van Houts, E (ed), 2004 The History of the Norman people: Wace's 'Roman de Rou', Boydell, Woodbridge

Cam, H M, 1959 'The city of Cambridge: bridges', in J P C Roach (ed), A History of the County of Cambridge and the Isle of Ely, 3, Oxford University Press, London, 114

Campbell, J, 2014 'A house is not just a home - means of display in English medieval gentry buildings', in M. Svart Kristansen and K. Giles (eds), Dwellings, Identities and Homes: European Housing Culture from the Viking Age to the Renaissance, Jutland Archaeological Society, Moesgaard, 175-184

Cervone, C S, 2008 'John de Cobham and the Cooling Castle's charter poem', Speculum 83, 884916

Chandler, H W, 1885 Five Court Rolls of Great Cressingham in the County of Norfolk, Eyre and Spottiswoode, London 
Chapter accepted in Kilby, SE;Gardiner, M, Perceptions of Medieval Settlement, 'Handbook of Later Medieval Archaeology', Oxford University Press (in press)

Coad, J G and Streeten, A D F, 1982 'Excavations at Castle Acre Castle, Norfolk, 1972-77: country house and castle of the Norman earls of Surrey', Archaeological Journal 139, 138-301

Cosgrove, D, 1985 'Prospect, perspective and the evolution of the landscape idea' Transactions of the Institute of British Geographers 10, 45-62

Creighton, O H, 2009 Designs Upon the Land: Elite Landscapes of the Middle Ages, Boydell, Woodbridge

Dyer, C, 1994 Everyday Life in Medieval England, Hambledon, London

Dymond, D, 1990 'A lost social institution: the camping close’, Rural History 1, 165-192

Dymond, D, 1999 'God's disputed acre', Journal of Ecclesiastical History 50, 467-497

Everson, P and Stocker, D, 2010 'Who at Wharram?', in S Wrathmell, Wharram. A Study of Settlement on the Yorkshire Wolds, XIII: A History of Wharram Percy and its Neighbours (York University Archaeological Publications 15), University of York, York, 262-277

Farrer, W, 1898 The Chartulary of Cockersand Abbey of the Premonstratensian Order, Chetham Society, Manchester

Fenwick, H, 2012 'Medieval moated sites in the Humber lowlands of England - landscape transformation, utilisation and social emulation', Medieval Archaeology 56, 283-292

Fernie, E, 2000 The Architecture of Norman England, Oxford University Press, Oxford

Field, R K, 2004 Court Rolls of Elmley Castle, Worcestershire, 1347-1564, Worcestershire Historical Society, Worcester

Gardiner, M F, 2008 'The wider context', in L Barber and G Priestley-Bell, Medieval Adaptation, Settlement and Economy of a Coastal Wetland: The Evidence from around Lydd, Romney Marsh, Kent, Oxbow Books, Oxford, 297-304

Gardiner, M F, 2012 'Oral tradition, landscape and the social life of place-names', in R Jones and S Semple (eds), Sense of Place in Anglo-Saxon England, Shaun Tyas, Donington, 16-30

Gardiner, M F, 2013, 'The sophistication of Late Anglo-Saxon timber buildings', in M D J Bintley and M G Shapland (eds), Timber, Trees and Woodland in Anglo-Saxon England, Oxford University Press, Oxford, 45-77

Gardiner, M F, forthcoming, 'Manorial farmsteads and the expression of lordship before and after the Norman Conquest', in D M Hadley and C C Dyer (eds), Transformations and Continuities in the Eleventh Century, Leeds, Society for Medieval Archaeology

Girouard, M, 1978 Life in the English Country House: A Social and Architectural History, Yale University Press, New Haven

Hallam, H E, 1965 Settlement and Society: a Study of the Early Agrarian History of South Lincolnshire, Cambridge University Press, Cambridge

Harte, J, 2003, 'Hell on earth: encountering devils in the medieval landscape', in B Bildhauer and R Mills (eds), The Monstrous Middle Ages, University of Toronto Press, Toronto, 177-195 
Chapter accepted in Kilby, SE;Gardiner, M, Perceptions of Medieval Settlement, 'Handbook of Later Medieval Archaeology', Oxford University Press (in press)

Herbert, J, 1985 'The transformation of hermitages into Augustinian priories in twelfth-century England', in W J Shiels (ed), Monks Hermits and the Ascetic Tradition (Studies in Church History 22), Basil Blackwell, Oxford, 131-145

Heslop, T A, 2000 'Weeting 'Castle', a twelfth-century hall house in Norfolk', Architectural History $43,43-57$

Hesse, M, 1998 'Medieval field systems and land tenure in South Creake, Norfolk', Norfolk Archaeology 43, 79-97

Hutton, R, 1994 The Rise and Fall of Merry England: the Ritual Year 1400-1700, Oxford University Press, Oxford

James, H, 1993 'The cult of St David in the Middle Ages', in M. Carver (ed), In Search of Cult: Archaeological Investigations in Honour of Philip Rabtz, Boydell, Woodbridge, 105-12

Johnson, M, 2002, Behind the Castle Gate: from Medieval to Renaissance, Routledge, London

Jones, E A, 1998 'The hermits and anchorites of Oxfordshire', Oxoniensia 63, 51-77

Jones, R, 2011 'Elemental theory in everyday practice: food disposal in the later medieval English countryside', Ruralia 8, 57-75

Jones, R, 2012 'Thinking through the manorial affix: people and place in medieval England' in S Turner and B Silvester (eds), Life in Medieval Landscapes: People and Places in the Middle Ages, Windgather, Oxford, 251-267

Kilby, S, 2010 'A different world? Reconstructing the peasant environment in medieval Elton', Medieval Settlement Research 25, 72-77

Kilby, S, 2013 'Encountering the environment: rural communities in England, 1086-1348' (unpub. PhD thesis, University of Leicester)

Kilby, S, 2015 'Mapping peasant discontent: trespassing on manorial land in fourteenth-century Walsham-le-Willows', Landscape History, 36:2, 69-88

Licence, T, 2003 'The Benedictines, the Cistercians and the acquisition of a hermitage in twelfthcentury Durham', Journal of Medieval History 29, 315-229

Licence, T, 2011 Hermits and Recluses in English Society, 950-1200, Oxford University Press, Oxford

Liddiard, R, 2005 Castles in Context: Power, Symbolism and Landscape, 1066-1500, Windgather Press, Macclesfield

Martin, D and Martin, B, 2004 New Winchelsea, Sussex: A Medieval Port Town, Heritage Marketing, King's Lynn

McNeill, T E, 2006 'The view from the top', Les Cabiers de l'Urbanisme hors série (Mélanges d'archéologie médiévale: liber amicorum en hommage à André Matthys), 122-25

Mellows, C and Mellows, W T, 1966, The Peterborough Chronicle of Hugh Candidus, Peterborough Museum Society, Peterborough

Mileson, S, 2012 'The South Oxfordshire Project: perceptions of landscape, settlement and society, c.500-1650', Landscape History 33:2, 83-98 
Chapter accepted in Kilby, SE;Gardiner, M, Perceptions of Medieval Settlement, 'Handbook of Later Medieval Archaeology', Oxford University Press (in press)

Mileson, $\mathrm{S}$ with a contribution by Brookes, S, forthcoming 'Openness and closure in the latermedieval village'

Müller, M, 2001 'Peasant mentalities and cultures in two contrasting communities in the fourteenth century; Brandon in Suffolk and Badbury in Wiltshire' (unpub. PhD thesis, University of Birmingham)

Mynard, D C and Zeepvat, R J, 1991 Excavations at Great Linford, 1974-80, Buckinghamshire Archaeological Society, Aylesbury

Noy, D (ed and trans), 2011 Winslow Manor Court Books, Part One, 1327-1377, Buckinghamshire Record Society, Aylesbury

Olson, S, 2009 A Mute Gospel, the People and Culture of the Medieval English Common Fields, Pontifical Institute of Mediaeval Studies, Toronto

Peers, C, 1953 Richmond Castle, Yorkshire, HMSO, London

Philp, B, 2011 Upper Walmer, Kent: The Norman Fortified Manor-House (Kent minor sites series, 21), Kent Archaeological Rescue Unit, Dover

Platt, C, 2010 'The homestead moat: security or status?', Archaeological Journal, 167, 115-133

Pugh, R B, 1970, Court Rolls of the Wiltshire Manors of Adam de Stratton, Wiltshire Record Society, Devizes

Ratcliff, S C (ed) and Gregory, D M (trans), 1946 Elton Manorial Records, 1279-1351, The Roxburghe Club, Cambridge

Reynolds, A, 2009 Anglo-Saxon Deviant Burial Customs, Oxford University Press, Oxford

Rippon, S, 2009 'Uncommonly rich and fertile' or 'not very salubrious'? The perception and value of wetland landscapes', Landscapes 1, 39-60

Roberts, B, 1968 'A study of medieval colonization in the Forest of Arden, Warwickshire', Agricultural History Review 16, 101-113

Rouse, E C, 1964 Longthorpe Tower, HMSO, London

Salzman, L F (ed), 1937 The Victoria History of the County of Sussex 9: Rape of Hastings, Oxford University Press for the Institute of Historical Research, Oxford

Semple, S, 1998 'A fear of the past: the place of the prehistoric burial mound in the ideology of middle and later Anglo-Saxon England', World Archaeology, 30:1, 109-126

Sharpe, R 2007, 'Which text is Rhygyfarch's Life of St David?', in St David of Wales. Cult, Church, and Nation, ed J. W. Evans and J. M. Wooding, (Woodbridge), 90-105

Sharpe, R and Davies, J R (ed. and trans), 2007 'Rhygyfarch's Life of St David', in St David of Wales. Cult, Church, and Nation, ed J W Evans and J M Wooding, (Woodbridge), 107-155

Smith, R, 1982 'Rooms, relatives and residential arrangements: some evidence in manor court rolls 1250-1500', Annual Report of the Medieval Settlement Research Group 30, 34-35

Smith, S V, 2010 'Houses and communities: medieval peasant experience', in C Dyer and R Jones (eds), Deserted Villages Revisited, University of Hertfordshire Press, Hatfield, 64-84 
Chapter accepted in Kilby, SE;Gardiner, M, Perceptions of Medieval Settlement, 'Handbook of Later Medieval Archaeology', Oxford University Press (in press)

Stone, D, 2005 Decision-Making in Medieval Agriculture, Oxford University Press, Oxford

Tilley, C, 2010 Explorations in Landscape Phenomenology 3: Interpreting Landscapes: Geologies, Topographies, Identities, West Coast Press, Walnut Creek (CA)

Walker, S S, 1983 The Court Rolls of the Manor of Wakefield from October 1331 to September 1333, Yorkshire Archaeological Society, Leeds

Walsham, A, 2011 The Reformation of the Landscape: Religion, Identity and Memory in Early Modern Britain and Ireland, Oxford University Press, Oxford

Watkins, C S, 2007 History and the Supernatural in Medieval England, Cambridge University Press, Cambridge

Whyte, N, 2003 'The after-life of barrows: prehistoric monuments in the Norfolk landscape', Landscape History 25, 1-16

Wood, M, 1965 The English Medieval House, Phoenix House, London

\section{Figure Captions}

Fig. 1 Scolland's Hall, Richmond Castle (N. Yorkshire) from the south. The position of the balcony overlooking the River Swale is marked by the row of joist holes below the lower tier of windows. The building on the left was constructed in the later twelfth century and blocked access to the balcony.

Fig. 2 Tofts at Great Linford (Buckinghamshire), showing the brewhouses also used for the sale of ale set towards the street, with the houses and farm buildings set behind (after Mynard and Zeepvat 1991, fig. 12).

\footnotetext{
${ }^{1}$ We are grateful to the late Lesley Boatwright for supplying this case.
} 